\title{
SOME OBSERVATIONS ON REPRODUCTION IN THE FEMALE GREEN ACOUCHI, MYOPROCTA PRATTI
}

\author{
BARBARA J. WEIR \\ Wellcome Institute of Comparative Physiology, \\ The Zoological Society of London, Regent's Park, London, N.W.1
}

(Received 19th March 1970)

\begin{abstract}
Summary. Acouchis (Myoprocta pratti) were investigated in the laboratory for comparison of their reproductive characteristics with those of other hystricomorphs. In this colony, the oestrous cycle length averaged $42 \cdot 7 \pm 2.5$ days; there was some indication of the existence of a summer and a lactation anoestrus. The gestation period was 99 days. The ovaries and reproductive tracts of these animals, and from animals obtained post mortem, were studied to complement a previous report on the ovarian histology in the acouchi. The presence of numerous accessory corpora lutea was confirmed but little interstitial tissue was found. Several ovaries contained groups of 'immature testis tubules'.
\end{abstract}

\section{INTRODUCTION}

In recent years, this hystricomorph rodent of the Family Dasyproctidae has been used for laboratory investigations. Breeding in captivity was reported by Wayre \& Wood (1961); husbandry in the laboratory was mentioned by Weir (1967a) and behavioural investigations have been made by Morris (1962), Lyall-Watson (1964) and Kleiman (1969). Information on the reproductive physiology of the species is sparse but some details were given by Weir (1967a, b) and by Kleiman $(1969,1970)$ and Rowlands, Tam \& Kleiman (1970) have related some aspects of ovarian histology to luteal and plasma progesterone levels in pregnant and non-pregnant acouchis.

All these data from studies on small numbers of animals indicate that the acouchi conforms to the general hystricomorph pattern in its reproductive processes. It has a vaginal closure membrane, a long gestation period (100 days), a long oestrous cycle (approximately 35 days), the young are precocious at birth and the ovary contains numerous accessory corpora lutea (cL). The present report provides further data on the physiology and histology of the ovaries and reproductive tract of the acouchi.

\section{MATERIALS AND METHODS}

The twenty-two acouchis examined in this series were from two sources (see Table 1). Some were kept in the laboratory for study of their reproductive patterns (Weir, 1967a); they were examined daily for vaginal opening and 
then killed at known stages of the reproductive cycle. The length of an oestrous cycle was determined as the interval from the lst day of vaginal opening at one cycle up to, but not including, the lst day of opening of the next cycle. Gestation periods were calculated from the time of mating, which was recognized by the finding of a copulatory plug or of spermatozoa in the vaginal smear. The other

TABLE 1

SOURGES AND OBSERVATIONS ON ACOUCHIS USED FOR THIS STUDY

\begin{tabular}{|c|c|c|c|c|c|c|c|c|c|}
\hline \multirow{2}{*}{$\begin{array}{c}\text { Animal } \\
\text { no. }\end{array}$} & \multirow{2}{*}{$\begin{array}{l}\text { Body } \\
w t \\
(g)\end{array}$} & \multirow{2}{*}{ Source } & \multirow{2}{*}{$\begin{array}{l}\text { Cause of } \\
\text { death }\end{array}$} & \multicolumn{3}{|c|}{$\begin{array}{l}\text { Histological } \\
\text { observations }\end{array}$} & \multirow{2}{*}{$\begin{array}{l}\text { Reproductive } \\
\text { state }\end{array}$} & \multicolumn{2}{|c|}{$\begin{array}{l}\text { No. of } \\
\text { eggs or } \\
\text { embryos }\end{array}$} \\
\hline & & & & Ovaries & Uterus & Vagina & & Left & Right \\
\hline $\begin{array}{l}\text { A } 11 \\
\text { A } 7 \\
\text { A } 17 \\
\text { A } 22\end{array}$ & $\begin{array}{r}83 \\
680 \\
620 \\
795\end{array}$ & $\begin{array}{l}\text { ZSL } \\
\text { ZSL } \\
\text { ZSL } \\
\text { ZSL }\end{array}$ & $\begin{array}{l}\text { Not suckled } \\
\text { Injured } \\
\text { Unknown } \\
\text { Injured }\end{array}$ & $\begin{array}{l}++ \\
++ \\
++ \\
++\end{array}$ & $\begin{array}{l}- \\
+ \\
+ \\
+\end{array}$ & $\begin{array}{l}- \\
+ \\
+\end{array}$ & $\begin{array}{l}\text { Neonatal } \\
\text { Immature } \\
\text { Non-pregnant } \\
\text { Non-pregnant, } \\
\text { parous }\end{array}$ & E & E \\
\hline A 12 & 910 & ZSL & Infection & -+ & + & - & $\begin{array}{l}\text { Non-pregnant, } \\
\text { parous }\end{array}$ & - & - \\
\hline $\begin{array}{l}\text { A } 8 \\
\text { A } 9 \\
\end{array}$ & $\begin{array}{l}760 \\
855\end{array}$ & $\begin{array}{l}\text { ZSL } \\
\text { ZSL }\end{array}$ & $\begin{array}{l}\text { Injured } \\
\text { Infection } \\
\end{array}$ & $\begin{array}{l}-+ \\
++\end{array}$ & $\begin{array}{l}- \\
- \\
\end{array}$ & $\begin{array}{l}- \\
-\end{array}$ & $\begin{array}{l}\text { Non-pregnant } \\
\text { Non-pregnant }\end{array}$ & - & - \\
\hline $\begin{array}{l}\text { A } 4 \\
\text { AF } 21\end{array}$ & $\begin{array}{r}1215 \\
870\end{array}$ & $\begin{array}{l}\text { Laboratory } \\
\text { Laboratory }\end{array}$ & $\begin{array}{l}\text { Killed } \\
\text { Killed }\end{array}$ & $\begin{array}{l}++ \\
+-\end{array}$ & $\begin{array}{l}+ \\
+\end{array}$ & $\begin{array}{l}+ \\
+\end{array}$ & $\begin{array}{l}\text { Oestrous, tubal } \\
\text { ova } \\
\text { Oestrous, } 4 \text { th } \\
\text { day of vaginal } \\
\text { opening }\end{array}$ & - & $\begin{array}{r}2 \\
-\end{array}$ \\
\hline $\begin{array}{l}\text { AF } 6 \\
\text { AF } 17 \\
\text { AF } 12 \\
\text { AF } 15 \\
\text { A } 6 \\
\text { AF } 1 \\
\text { A } 1 \\
\text { AF } 20\end{array}$ & $\begin{array}{r}1255 \\
982 \\
1163 \\
1108 \\
890 \\
1333 \\
1050 \\
1082 \\
\end{array}$ & $\begin{array}{l}\text { Laboratory } \\
\text { Laboratory } \\
\text { Laboratory } \\
\text { Laboratory } \\
\text { ZSL } \\
\text { Laboratory } \\
\text { Laboratory } \\
\text { Laboratory }\end{array}$ & $\begin{array}{l}\text { Killed } \\
\text { Killed } \\
\text { Killed } \\
\text { Killed } \\
\text { Infection } \\
\text { Killed } \\
\text { Killed } \\
\text { Killed }\end{array}$ & $\begin{array}{l}-+ \\
+- \\
+- \\
++ \\
++ \\
+\frac{+}{+} \\
++\end{array}$ & $\begin{array}{l}+ \\
+ \\
- \\
+ \\
+ \\
+ \\
-\end{array}$ & $\begin{array}{l}+ \\
+ \\
+ \\
+ \\
+ \\
+ \\
+\end{array}$ & $\begin{array}{l}\text { Pregnant } 20 \text { days } \\
\text { Pregnant } 29 \text { days } \\
\text { Pregnant } 45 \text { days } \\
\text { Pregnant } 60 \text { days } \\
\text { Pregnant } 70 \text { days } \\
\text { Pregnant } 75 \text { days } \\
\text { Pregnant } 90 \text { days } \\
\text { Pregnant } 90 \text { days }\end{array}$ & $\begin{array}{l}1 \\
0 \\
0 \\
1 \\
1 \\
0 \\
2 \\
2 \\
\end{array}$ & $\begin{array}{l}1 \\
2 \\
2 \\
1 \\
1 \\
2 \\
0 \\
0\end{array}$ \\
\hline $\begin{array}{l}\text { A } 21 \\
\text { A } 23 \\
\text { AF } 13\end{array}$ & $\begin{array}{r}1530 \\
917 \\
1050\end{array}$ & $\begin{array}{l}\text { ZSL } \\
\text { ZSL } \\
\text { Laboratory }\end{array}$ & $\begin{array}{l}\text { Unknown } \\
\text { Unknown } \\
\text { Killed }\end{array}$ & $\begin{array}{l}++ \\
++ \\
--\end{array}$ & $\frac{-}{+}$ & $\begin{array}{l}- \\
-\end{array}$ & $\begin{array}{l}\text { Post-partum } \\
\text { Post-partum } \\
\text { Post-partum, } 5 \\
\text { days, not suck- } \\
\text { ling }\end{array}$ & $\begin{array}{c}\overline{0} \\
-\end{array}$ & $\overline{1 *}$ \\
\hline AF 14 & 1030 & Laboratory & Killed & ++ & + & + & $\begin{array}{l}\text { Post-partum, } 10 \\
\text { days, suckling }\end{array}$ & & \\
\hline AF 16 & 1972 & Laboratory & Killed & -+ & - & - & $\begin{array}{l}\text { Post-partum, } 21 \\
\text { days, suckling }\end{array}$ & - & - \\
\hline
\end{tabular}

+, Studied; - , not available for study. A-present series; AF-series of Rowlands et al. (1970). ZSL, Zoological Society of London.

* Determined by distension of this horn.

animals were obtained post mortem from the Zoological Society of London and the previous reproductive history was usually unknown. Details of the animals on which observations were made are given in Table 1, and the material studied by Rowlands et al. (1970) is also included for comparison.

The ovaries and reproductive tract were examined macroscopically and fixed in Bouin's fluid. Representative paraffin wax sections were cut at $4 \mu$ of all tissues except ovaries which were serially sectioned at $5 \mu$ and every fifth section 
mounted. If ovulation had taken place recently, the Fallopian tubes were similarly treated. The routine stain used was Mayer's haemalum and eosin, but Heidenhain's azan and periodic-acid-Schiff were also used. In acouchis, the remains of the zona or the egg are very prominent in follicles which luteinize without the occurrence of ovulation. Such follicles were diagnosed as accessory GL and in general they were smaller than the true CL.

Standard statistical methods were applied and all values expressed as means \pm the standard error of the mean. Volumes were calculated from the product of the three diameters of the subject multiplied by 0.523 , on the assumption that the bodies were spherical.

\section{RESULTS}

\section{Observations on living animals}

The mean oestrous cycle length for each of four females was $37.7 \pm 2.5$ days $(\mathbf{N}=3) ; 37.4 \pm 1.7$ days $(\mathbf{N}=7) ; 39 \cdot 4 \pm 4.5$ days $(\mathbf{N}=5)$ and $54 \cdot 0 \pm 5 \cdot 1$ days $(\mathrm{N}=6)$; the overall mean was $42 \cdot 7 \pm 2 \cdot 5$ days $(\mathrm{N}=21)$. The majority of these cycles occurred during autumn, winter and spring, although in two animals cycles also occurred regularly throughout the summer. However, the interval between consecutive oestrous periods was longer in five other instances $(82.4 \pm$ 12.3 days) during the summer months. This interval was significantly longer $(P<0.001)$ than intervals between cycles occurring at other times of year.

After parturition, the next period of vaginal opening appeared to depend on whether or not the young were suckled. In two animals suckling their young and housed with a male throughout, the next oestrus after parturition was at 50 and 51 days. When the young died at or soon after birth, one achouchi successfully mated within 4 days of parturition, while, in three other animals, the vagina closed after the birth, then re-opened, and fertile matings took place 13, 16 and 18 days after parturition.

Seven pregnancies were brought to term and for five of these, the gestation length was 99 days. The other two pregnancies, where the exact day of conception was unknown, were calculated from the known time of vaginal opening and were 100 to 104 and 99 to 106 days in duration.

The sex ratio of the six singletons and one pair born was $6 \hat{0} 0 \hat{0}: 29+9$. The pair consisted of one of each sex.

\section{Macroscopic anatomy}

The reproductive tract has been described by Weir (1967b), Kleiman (1969) and Rowlands et al. (1970). It is very similar to that of the agouti (Weir, 1971), except that the cervix is not as muscular.

\section{Microscopic anatomy}

Since some of the basic ovarian cell associations of acouchis have been described by Rowlands et al. (1970), the present material is arranged according to the presumed physiological status of the animal (see Table 1).

The non-pregnant female. The first seven animals listed in Table 1 can be arranged in a series from the neonatal stage through adolescence to maturity. 
In the neonatal ovaries of A 11, the cell types were arranged as in other mammals, with cortical oocytes and cortical and medullary follicles. None of the follicles contained more than two layers of epithelial cells and several were binovular. No primary interstitial tissue was seen.

The ages of A 7 and A 17 were not known but the state of their ovaries, uterus and vagina indicated that they had not reached puberty. Only small antral follicles $(<600 \mu$ in diameter), usually having a well developed theca interna, were present. Vascularized connective tissue filled the central portions of each ovary and the remaining tissue consisted of densely packed stromal cells. A few small patches of interstitial tissue were found in A 17. In both animals, the endometrium was shallow and there were few glands; the vaginal epithelium was only two cell layers thick and looked inactive.

Acouchis A 12 and A 22 were both reported to be parous, and although none of the ovaries contained CL of ovulation, each contained numerous accessory CL. Follicle diameters in A 12 did not exceed $400 \mu$, but there were many normal and atretic follicles up to $600 \mu$ in diameter in A 22. Some interstitial tissue patches were seen in both animals, but the bulk of these ovaries consisted of dense stromal cells. The uteri did not appear active; the endometrium was shallow and there were few glands, but the condition of the uterine blood vessels confirmed that the animals had been pregnant.

No previous reproductive history was known for either A 8 or A 9, which were reported as being 9 months and 2 years 8 months of age, respectively. Follicles up to $600 \mu$ in diameter were present in both animals and there were numerous accessory CL. Each ovary also contained one large cL (diameter $2000 \mu$ ) which was presumably derived from an ovulated follicle. The CL of A 9 were old judging by their histological appearance (Pl. 2, Fig. 5), while that in the only available ovary of A 8 (Pl. 2, Fig. 4) was well vascularized and still had a central core of extravasated blood. In this acouchi, some extra-ovarian tubules resembling 'immature testis tubules' (see P1. 2, Fig. 2) were found. Unfortunately, neither the uteri nor the vaginae of these animals were collected so no further deductions can be made about their reproductive states.

The oestrous female. Acouchi A 4 was killed on the lst day of vaginal opening of a cycle. There were two new GL of ovulation in the right ovary (Pl. 1, Fig. 1), each with a stigma and central lumen. There were two ova in the corresponding Fallopian tube (Pl. 2, Fig. 8). The new cL were both $0.8 \mathrm{~mm}^{3}$, and there were

\section{EXPLANATION OF PLATE I}

FIG. 1. Section through the ovary of A 4, killed on the 1st day of vaginal opening, showing two CL of ovulation and several luteinizing follicles (arrowed). Part of the connective tissue core and a few small follicles can also be seen; the rest of the ovary consists of densely packed stromal cells. Bouin, $5 \mu, \mathrm{H} \& \mathrm{E} ; \times 12 \cdot 6$.

Fig. 2. Part of the ovary of A 1. The edge of a GL of pregnancy can be seen (below) and a patch of 'immature testis tubules' (above), separated by a band of rete ovarii tubules. Bouin, $7 \mu, \mathbf{H} \& \mathbf{E} ; \times 74$.

Fic. 3. Part of the ovary of A 12 to show atretic follicles. The lower follicle shows a central egg remnant surrounded by luteinized membrana granulosa cells. There is a wide theca interna with densely packed cells and a narrow theca externa. The other two follicles (upper and right) have a luteinized granulosa, but between this and the theca externa, and apparently derived from the theca interna cells, are typical interstitial cells. Stromal cells pack the rest of the section. Bouin, $5 \mu, \mathbf{H} \& \mathrm{E} ; \times 250$. 
PL.ITE I
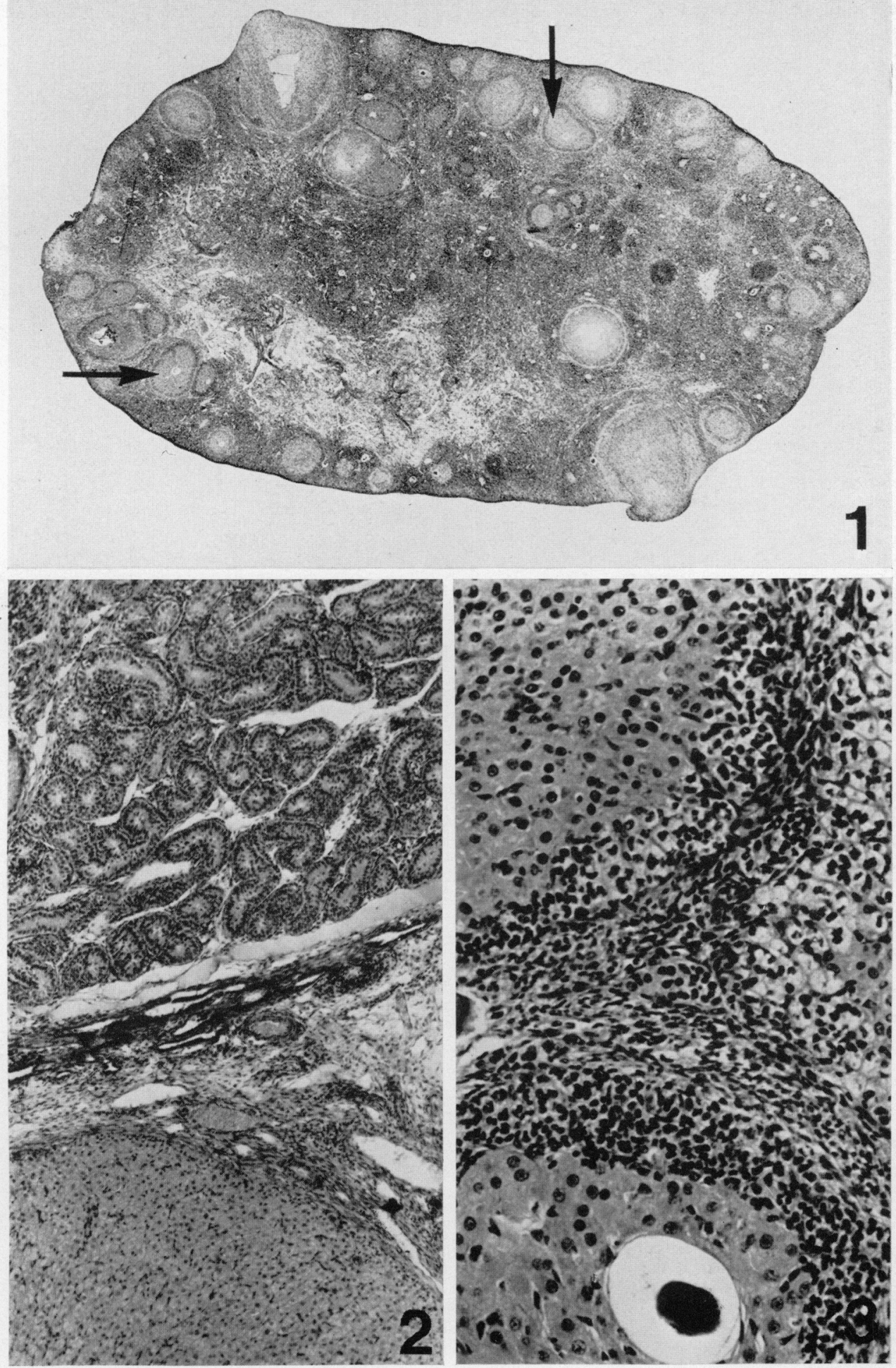
PLATE 2
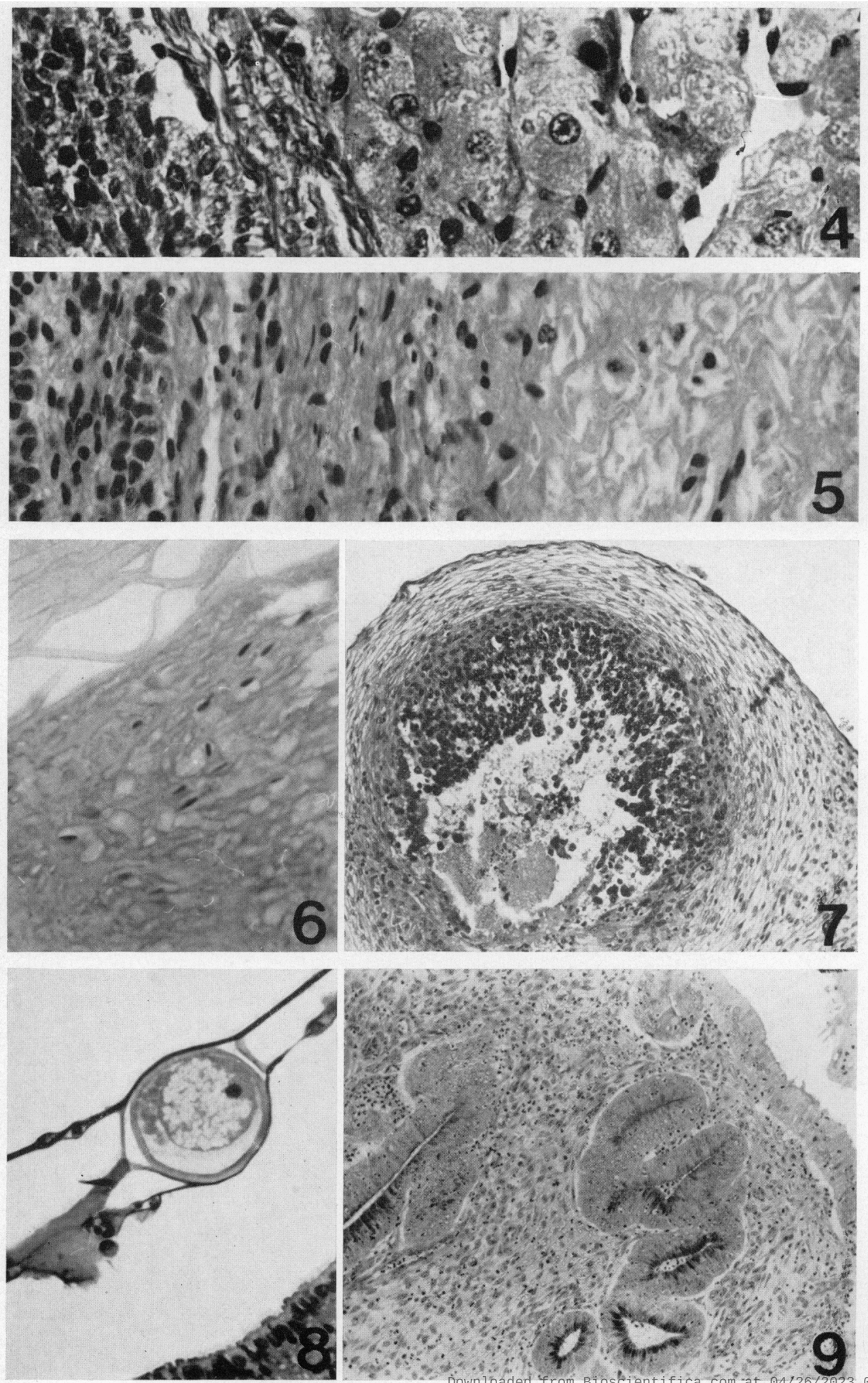
two older cL in the same ovary which were 1.1 and $0.9 \mathrm{~mm}^{3}$ in volume. There were no larger GL in the left ovary, but both contained very many accessory CL. In the left ovary alone, 189 lutein bodies with zonal remains were counted, and since there were several CL in which these remains were no longer visible, the total numbers of accessory $\mathrm{CL}$ in this animal must have been about 500 . None of the accessory CL was greater than $600 \mu$ in diameter, but all the remaining follicles greater than $100 \mu$ diameter were luteinizing. 'Immature testis tubules' were also found in both ovaries of this acouchi. The endometrium appeared active; there were many glands and the lining epithelium was tall.

Acouchi AF 21 was killed on the 4th day of vaginal opening, but it was not possible to establish whether or not ovulation had occurred as one ovary was used for progesterone analysis (Rowlands et al., 1970). The left ovary contained only small follicles, several small accessory aL $(<500 \mu$ diameter $)$ and one large follicle ( $1000 \mu$ diameter) which appeared to be in the early stages of luteinization. As such luteinization may precede ovulation in this species, the animal may be considered as pre-ovulatory on this evidence. However, Rowlands et al. (1970) found a very high progesterone concentration $(211 \mathrm{ng} / \mathrm{mg})$ in the single, very small aL removed from the right ovary. The plasma progesterone was low $(12.6 \mathrm{ng} / \mathrm{ml})$, which may indicate that ovulation had taken place. The vaginal epithelium was cornifying and there was no mucus present, indicating an advanced stage of oestrus. The uterus, like that of A 4, had an active endometrium and long straight glands.

The pregnant female. The stages of pregnancy represented by A 6 and A 1 could not be exactly determined, but by reference to the AF series of Rowlands et al. (1970), A 6 was probably 65 to 70 days pregnant and A 1 was about 85 to 90 days. The cL of pregnancy in A 6 were 1.18 and $1.23 \mathrm{~mm}^{3}$ and were centrally situated in the ovary as described by Rowlands et al. (1970). The accessory CL varied in size and were well vascularized; there were sixty-one in one ovary and seventy-nine in the other. Follicles, up to $700 \mu$ in diameter, were present but many were atretic. In A 1 , where both foetuses were in the left horn of the uterus, there were four large GL in the left ovary and one in the right. The largest

\section{EXPLANATION OF PLATE 2}

Fig. 4. Part of the cL of A 8. It is well vascularized and has a central lumen of extravasated blood, indicating recent formation. Bouin, $5 \mu, \mathrm{H} \& \mathrm{E} ; \times 560$.

FIG. 5. Part of one of the two CL in A 9; they were $2 \mathrm{~mm}$ in diameter, but were considered to be the oldest in this series of acouchis. Bouin, $5 \mu, \mathrm{H} \& \mathrm{E} ; \times 560$.

FIG. 6. Section through the copulatory plug of an acouchi. The dark sperm heads can be seen trapped in the male accessory gland secretions (below) and the cornified material (above) is part of the vaginal epithelium of the female which is sloughed as the plug is expelled. Bouin, $4 \mu, \mathrm{H} \& \mathrm{E} ; \times 590$.

FIG. 7. Section through a mesometrial blood vessel of A 1 which was about 90-days pregnant. Macroscopically these vessels appear white and bloodless. Bouin, $7 \mu, \mathrm{H} \& \mathrm{E}$; $\times 120$.

Fig. 8. Ovum in the Fallopian tube of A 4 which had recently ovulated (see P1. 1, Fig. 1). $\mathrm{F} / \mathrm{S}, 5 \mu, \mathrm{H} \& \mathrm{E} ; \times 250$.

FIG. 9. Section of the uterus of a post-partum acouchi (AF 13), showing the active endometrium, the PAS-positive apical parts of the gland cells and the leucocytosis which is common in the acouchi at all stages of the cycle. Bouin, $4 \mu, \mathrm{PAS} ; \times 110$. 
CL was $3.36 \mathrm{~mm}^{3}$ and the smallest was $1.47 \mathrm{~mm}^{3}$. There were also 137 accessory CL in the left ovary and ninety-one in the right. There were small follicles ( $<300 \mu$ diameter) in both ovaries, but in the ovary containing the single CL, there was an apparently mature, normal follicle of $1400 \mu$ diameter with a well formed cumulus oophorus. The ovaries of this acouchi were characterized by the presence of large masses of tubules resembling 'immature testis tubules' (Pl. 1, Fig. 2). In one ovary, they occupied $0.53 \mathrm{~mm}^{3}$, and in the other, 0.44 $\mathrm{mm}^{3}$. Patches of similar tubules were observed in AF 17 and AF 15.

The ovaries of the pregnant AF series have been described by Rowlands et al. (1970) and little needs to be added in this account. Normal follicles, up to $800 \mu$ in diameter, were present in the ovaries of all except AF 1, in which they were cystic. Many follicles of AF 15 (60 days pregnant) were luteinizing and all the ovaries contained varying numbers of already formed accessory cL. The central connective tissue core was prominent and apart from a few small patches of interstitial tissue in some animals, the remaining ovarian tissue was of densely packed stromal cells, frequently containing hyalinized or atretic eggs (see Pl. 1, Fig. 1).

As in the guinea-pig, the vaginal epithelium becomes progressively more folded and mucified as pregnancy advances. Parts of the uterus not involved in the decidual reaction did not differ greatly from the picture seen in the nonpregnant acouchi. The difference between parous and non-parous acouchis was most clearly seen by the condition of the blood vessels of the uterus. In pregnancy, the walls of these vessels become occluded (Pl. 2, Fig. 7), and, macroscopically, appear to be white and bloodless.

The post-partum female. The exact times of parturition were not known for A 21 and A 23, but they were probably not more than 3 days before death. The CL of A 21 were $1.32,1.46$ and $1.26 \mathrm{~mm}^{3}$ and histologically appeared to be those of the antecedent pregnancy. The three largest CL in the right ovary of A 23 were only about $1000 \mu$ in diameter and had centrally extravasated blood. It was impossible to determine the age of these CL since the specimens were badly affected by post-mortem changes. Both animals had numerous accessory CL some of which were nearly $1000 \mu$ in diameter. The follicles in A 23 were not greater than $700 \mu$ in diameter, and most of those in A 21 were about $500 \mu$, but five had a diameter greater than $1000 \mu$. Two of these large follicles looked normal and the other three were beginning to luteinize.

The ovaries of AF 13 ( 5 days post partum, not suckling) were not available for study but the uterus appeared active, with the apical parts of the gland cells being PAS-positive (Pl. 2, Fig. 9). The uterus of AF 14 (10 days post-partum, suckling) was of similar appearance but this animal had no large follicles or new cL of ovulation. The ovary associated with the parous uterine horn contained three GL $(800 \mu$ in diameter), which were probably those of the recent pregnancy, and accessory CL of up to $600 \mu$ in diameter. The vaginal epithelium was two- to three-cell layers thick and there was very little mucus present. Only the right ovary of AF 16 (21 days post partum, suckling) was available for study. There were two small corpora albicantia, ninety-four accessory GL and follicles of up to $600 \mu$ in diameter, but most of these were atretic. The vagina appeared completely inactive. 


\section{DISGUSSION}

In several aspects, the present study confirms observations made on this species by Weir (1967a, b), Kleiman (1970) and Rowlands et al. (1970), including the formation of copulatory plugs (Pl. 2, Fig. 6). However, there are some discrepancies between this study and that of Kleiman (1970), who was primarily concerned with reproductive behaviour. She did not report the occurrence of longer oestrous cycles during the summer months, but the significant differences found in the present study seem to indicate that the acouchi may have a summer anoestrus. A similar finding has been reported for other hystricomorphs (chinchilla: Weir, 1966; agouti: Weir, 1967a, 1971). In the present study, it was found that the vaginal membrane closed and re-opened for a fertile oestrus soon after parturition when the young died at birth. Kleiman did not observe this because her animals were not disturbed 'for a few days' after parturition, and she states that the vagina remains open for 3 to 45 days at this time. A mid-lactation oestrus at $25 \pm 4$ days after parturition was reported by Kleiman for eleven animals housed with males; this mean is longer than the intervals found for nonsuckling females in the present study. Kleiman also found that seven females kept alone did not come into oestrus until $54 \pm 3$ days after parturition, but for none of these animals was any distinction made between suckling and nonsuckling females. It seems possible that all Kleiman's isolated females were suckling and that the interval given represents the lactation anoestrus noted in the present study which appeared to occur in two acouchis housed with males. Since other hystricomorph species have been shown to exhibit the phenomenon of a lactation anoestrus (chinchilla: Weir, 1967b; wild guinea-pig, Galea musteloides: Rood \& Weir, 1970; plains viscacha: Weir, in preparation), it would seem more likely that concurrent lactation, rather than isolation, is the cause of delayed onset of oestrus after parturition in the acouchi.

The occurrence of an immediate post-partum oestrus with ovulation in the acouchi is equivocal. From intervals between births of succeeding litters, Kleiman (1970) found a few instances of post-partum conceptions although no evidence of mating was seen at these times. Rowlands et al. (1970) considered that one (AF 16) of the three post-partum acouchis had ovulated and this was a lactating female that was said to have mated on the 5th day after parturition. In the present series, the small numbers of post-partum ovaries available do not help to clarify ovarian events. There was no evidence that A 21 or A 23 had experienced a post-partum ovulation. The age of the CL of A 23 could not be determined. If these cL had been formed after ovulation or derived from luteinization of unovulated follicles, the CL of the pregnancy must have regressed very quickly, although CL related to the pregnancy were still identifiable in A 21. No egg or zonal remains were found in the cL of A 23, but it is probable that they were luteinizing follicles, especially as there were no other follicles larger than $700 \mu$ in the ovaries. In one ovary of A 21, there were several large ripe follicles and some of these were undergoing luteinization, indicating that perhaps an LH surge had occurred and was insufficient to cause ovulation. It is possible that coitus might act as an extra stimulus to ensure ovulation at this 
time. Some other hystricomorph species are believed to be induced ovulators (tuco-tuco, degu: Weir, unpublished observations).

The basic pattern of ovarian events in the acouchi would seem to be as follows: an antrum appears in follicles when they are about $300 \mu$ in diameter and the ripe Graafian follicle reaches a diameter of about $1200 \mu$. The theca interna is well marked and a theca externa is present but not prominent. One to five ova are ovulated from one or both ovaries. The true cL grows to a maximum of $2500 \mu$ in diameter but cL do not seem to persist long beyond the length of the cycle or of pregnancy. The corpora albicantia reported in AF 16 (Rowlands et al., 1970) are unusual for hystricomorphs. The accessory CL, clearly formed from luteinization of the membrana granulosa cells, are very numerous and in histological sections can be readily distinguished from the true cL by their smaller size and by the persistent remains of degenerate eggs and zonae (Pl. 1, Figs. 1 and 3). Although interstitial tissue is usually found in small patches only, interstitial cells can be formed from the theca interna cells (Pl. 1, Fig. 3) as in other mammals. The remaining tissues of the acouchi ovary are the densely packed stromal cells and the loose, and sometimes extensive, connective tissue core. Bilateral 'immature testis tubules' are found in some individuals.

It was not possible to establish a uterine cycle on such a small series of animals, but the depth of the endometrium and its epithelium and the glandular activity was noticeable in A 4, AF 13 and AF 21, all of which probably had recent CL in the ovaries. Many leucocytes were present in all the uterine and vaginal sections examined and their occurrence is probably normal for this species. The vaginal cycle follows the usual rodent pattern of mucification and cornification.

Although the acouchi and the agouti are members of the same family, the ovaries are characteristically different. Testis tubules commonly occur in both and they were present in eight of the thirty-six agoutis and acouchis examined. The tubules of the acouchi are slightly smaller in diameter than those of the agouti, but, as Pl. 1, Fig. 2 shows, they are clearly not derived from rete ovarii. Similar tubules have been reported in individuals of various mammalian species (League \& Hartman, 1925; Wilcox \& Mossman, 1945). There is little, if any, stromal tissue in the agouti ovary, and an extensive connective tissue is unusual. The major tissue type of the agouti is of interstitial cells and these are derived from atretic follicles. Like those of the acouchi, many agouti follicles are also luteinized without the occurrence of ovulation and this formation of accessory CL is common throughout the hystricomorphs (Canadian porcupine: Mossman \& Judas, 1949; mountain viscacha: Pearson, 1949; chinchilla: Weir, 1966; coypu: Rowlands \& Heap, 1966; plains viscacha: Weir, in preparation). A study of different hystricomorph species emphasizes again the variability of ovarian morphology, and presumed physiology, within this rodent sub-order.

\section{ACKNOWLEDGMENTS}

This study was supported in part by the Agricultural Research Council and by the Ford Foundation. The photographs were taken on a Zeiss Ultraphot microscope provided by the Wellcome Trust. My thanks are due to Professor Sir Alan Parkes and Dr I. W. Rowlands for their constant help and encourage- 
ment, and to the pathologist of the Zoological Society of London, Dr I. F. Keymer, for permission to collect material from post-mortem specimens of acouchis. Permission to study the AF series of Rowlands et al. (1970) is much appreciated.

\section{REFERENCES}

Kleiman, D. G. (1969) The reproductive behaviour of the green acouchi, Myoprocta pratti. Ph.D. thesis, University of London.

Kleiman, D. G. (1970) Reproduction in the female green acouchi, Myoprocta pratti Pocock. F. Reprod. Fert. 23, 55.

League, B. \& Hartman, C. G. (1925) Anovular Graafian follicles in mammalian ovaries. Anat. Rec. 30,1 .

Lyall-Watson, M. (1964) The ethology of food-hoarding in mammals with special reference to the green acouchi Myoprocta pratti. Ph.D. thesis, University of London.

Morris, D. (1962) The behaviour of the green acouchi (Myoprocta pratti) with special reference to scatter hoarding. Proc. zool. Soc. Lond. 139, 701.

Mossman, H. W. \& Judas, I. (1949) Accessory corpora lutea, luteal cell origin, and the ovarian cycle in the Canadian porcupine. Am. F. Anat. 85, 1.

Pearson, O. P. (1949) Reproduction of a South American rodent, the mountain viscacha. $\mathrm{Am}$. $\mathcal{F}$. Anat. 84, 143.

Roon, J. P. \& WeIR, B. J. (1970) Reproduction in female wild guinea-pigs. 7. Reprod. Fert. $23,393$.

Rowlands, I. W. \& HEAP, R. B. (1966) Histological observations on the ovary and progesterone levels in the coypu Myocastor coypus. Symp. zool. Soc. Lond. 15, 335.

Rowlands, I. W., TaM, W. H. \& KLeiman, D. G. (1970) Histological and biochemical studies on the ovary and progesterone levels in the systemic blood of the green acouchi (Myoprocta pratti). 7. Reprod. Fert. 22, 533.

Wayre, P. \& Wood, J. G. P. (1961) Some experiences of breeding green acouchis (Myoprocta pratti) in captivity. Int. Zoo $\mathrm{Yb} .3,25$.

WEIR, B. J. (1966) Aspects of reproduction in chinchilla. 7. Reprod. Fert. 12, 410.

Weir, B. J. (1967a) The care and management of laboratory hystricomorph rodents. Lab. Anim. 1, 95.

WEIR, B. J. (1967b) Aspects of reproduction in some hystricomorph rodents. Ph.D. thesis, University of Cambridge.

WEIR, B.J. (1971) Some observations on reproduction in the female agouti, Dasyprocta aguti. J. Reprod. Fert. 24, 203.

Wilcox, D. E. \& Mossman, H. W. (1945) The common occurrence of 'testis' cords in the ovaries of a shrew (Sorex vagrans, Baird). Anat. Rec. 92, 183. 